\title{
Pertumbuhan Rumput Laut Gracilaria sp. Greville, 1830 (Rhodophyta: Florideophyceae) di Tambak Tidak Produktif Mangunharjo Tugu Semarang
}

\author{
Chrisna Adhi Suryono*, Irwani, Agus Sabdono, Rudhi Pribadi, Wilis Ari Setyani, Agus Indarjo \\ Departemen IImu Kelautan, Fakultas Perikanan dan IImu Kelautan Universitas Diponegoro \\ Jl. Prof. H. Soedarto S.H, Tembalang Semarang, Jawa Tengah 50275 Indonesia \\ ${ }^{*}$ Corresponding author, e-mail: cas8348@gmail.com
}

\begin{abstract}
Abstrak : Rumput laut Gracilaria sp. merupakan salah satu hasil produk laut yang masih memiliki permintaan yang tinggi di pasar. Permasalahan yang ada masih rendahnya suplai karena masih banyak mengandalka hasil alam. Tujuan dari penelitian ini melihat pertumbuhkan rumput laut tersebut di tambak yang tidak produktif. Metoda yag digunakan adalah lepas dasar sesui dengan hidupnya di alam. Pegukuran dilakuna terhadap 10 contoh rumput laut yang memiliki berat awal sama $\pm 20 \mathrm{gr}$, pengukuran berat dilakukan setiap 10 hari. Hasil penelitian menunjukan bahwa Gracilaria mampu tumbuh di tambak dengan awal yang lambat kemudian meningkat setalah hari ke 30. Uji Anova terhadap berat tiap pengukuran menunjukan perbedaan yang sangat signifikan $(p=0.00 \leq 0,01)$. Kualitas perairan tambak secara keseluruhan mendukung untuk pertumbuhan rumput laut Gracilaria sp.
\end{abstract}

Kata kunci: Gracilaria sp., tambak, metoda lepas dasar

The Growth of Seaweed Gracilaria sp. Greville, 1830 (Rhodophyta: Florideophyceae) in Non Productive Brackish Waters Pounds Mangunharjo Tugu Semarang

Abstrack : Gracilaria sp seaweed one of marine commodity which still has high demand in the market. The problem of these produck was a supply still low because the min supplay depand on nature produck. This study aims to determine the growth of seaweed in non productive brackish waters pounds. Off-bottom method was used to application seaweed growth on brackish fish pounds such as life in nature. Measurement of weigh was carried out on 10 samples of seaweed which had the same initial weight of \pm 20 grams, weight measurements were carried out every 10 days. The results showed that Gracilaria was able to grow in ponds with a slow start and then increased dramatically after 30 days. Anova test on the weight of each measurement showed a very significant difference $(p=0.00 \leq 0.01)$. Futher more the quality of pond waters was supports to growth of Gracilaria sp.

Keywords: Gracilaria sp, brackish waters pounds, off bottom method

\section{PENDAHULUAN}

Kawasan pesisir Tugu Kota Semarang masih terdapat tambak baik yang produktif maupun tidak produktif. Adanya tambak yang tidak produktif tersebut diupayakan pemanfaatanya untuk budidaya produk lain seperti rumput laut maupun kerang darah. Rumput laut Gracilaria sp dibudidaya di tambak karena memiliki toleransi salinitas yang tinggi antara 15-30 ppt (Indriani dan Suminarsih, 2003). Budidaya gracilaria sudah banyak dilakukan di berbagai belahan dunia terutama Asia, Amerika Selatan, dan Afrika Selatan (FAO, 2012). Budidaya gracilaria tergolong relatif aktivitas teknologi rendah dan tidak membutuhkan personel khusus. Oleh karena itu, budidaya Gracilaria sangat menarik dan memiliki potensi yang cukup besar untuk berkontribusi dalam pembangunan ekonomi masyarakat pesisir (Marinho-Soriano et al., 2006). Gracilaria termasuk alga coklat yang banyak dimafaatkan oleh karena itu banyak dibudidayaan di daerah tropis dan sub tropis karena memiliki banyak manfaat untuk produksi mkanan, farmasi maupun sintesa produk lain seperti ati mikroba dan pathogen dan bahan bakar (biofieul) (Zemke-White \& 
Ohno.,1999; FAO, 2012; Vatsos \& Rebours, 2015; Thanigaivel et al., 2016). Gracilaria merupakan sumber penghasil agarofit di dunia sekitar $60 \%$ (Tseng, 2001). Tingginya permintaan komoditas rumput laut untuk kebutuhan industri di dalam dan luar negeri, maka harus diimbangi dengan upaya penyediaan bahan baku yang berkualitas dan berkesinambungan (Rejeki et al., 2018). Tingginya kebutuhan agarofit di dunia tentunya tidak dapat dicupi dari hasil alam namun harus dari budidaya. Budidaya alga coklat seperti Gracilaria telah banyak di lakukan di berbagai negara terutama Asia, Amerika Latin dan Afrika Selatan (McLachlan \& Bird,1986; Marinho-Soriano et al. 2006). Pengambilan rumput laut dari alam dalam jumlah besar dapat mengganggu keseimbangan komunitas hewan dan tumbuhan di lokasi serta mempercepat erosi pantai. Oleh karena itu, dibutuhkan pemenuhan rumput laut dari hasil budidaya karena lebih sederhana dan lebih efisien (Parker, 2012). Usaha budidaya rumput laut yang dilakukan di perairan Indonesia pada umumnya memakai tiga metode budidaya, yaitu metode lepas dasar, metode rakit apung, dan metode rawai panjang, namun budidaya rumput laut di tambak untuk Gracillia umumnya dilakukan secara lepas dasar. Pemilihan metode penanaman rumput laut terkait erat dengan kondisi perairan dan skala usaha yang akan diterapkan (Putra et al., 2011). Informasi diatas sebagai dasar tujuan penelitian masyarakat untuk budidaya rumput dengan metoda lepas dasar.

\section{MATERI DAN METODE}

Penelitian dilakukan pada bulan September - Nopember 2020 di pertambakan Mangunhrjo Semarang. Materi yang digunakan dalam penelitian ini adalah rumput laut Gracilaria sp yang di dapat dari pertambakan Brebes. Rumput laut ditanam dengan mengguakan metoda lepas dasar sesuai dengan kehidupanya di alam (Putra et al., 2011). Sepuluh sampel rumput laut dengan berat awal $20 \mathrm{gr}$ ditanan secara acak didasar tambak. Pengukuran pertumbuhan relatif diamati setiap 10 hari sampai hari ke-50 dengan menggunakan timbangan elektrik. Model pengukuran relatif mengcu pada (Putra et al., 2011). Data pertumbuhan dan penembahan berat setiap 10 hari diuji dengan Anova menggunkan Minitab. Kualitas air tambk yang diukur meliputi salinitas, suhu air, pH, Nitrat dan Posfat terlarut dengan menggunakan Water Quality Cheker.

\section{HASIL DAN PEMBAHASAN}

Hasil pengamatan terhadap pertumbuhan Gracilaria di tambak di Mangunharjo Kota Semarang menunjukan adanya pertambahan berat selama pengamatan 50 hari yang diukur setiap 10 hari. Gambar 1 menunjukan peningkatan pertumbuhan sejak awal penanaman hingga pengukuran hari ke 50, peningkatan tertinggi terlihat pada pengukuran hari ke 40 ke hari 50 dengan peningkatan 22gr. Banyak faktor yang berpengaruh terhadap pertumbuhan Gracilaria seperti salinitas, kedalaman air, $\mathrm{pH}$, nitrat terlarut dan posfat terlarut (Widyorini, 2010; PongMasak and Sarira, 2015; Aslan, 1998; Ruslaini, 2016).

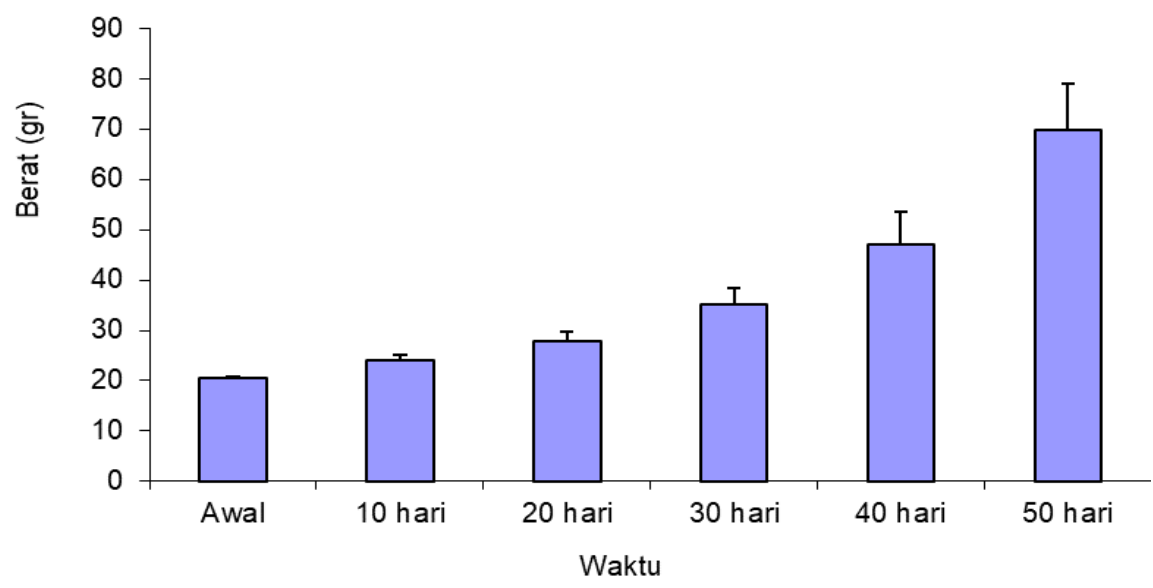

Gambar 1. Rata rata pertumbuhan \pm SD rumput laut Grcillaria sp. di Tambak Mangunharjo 
Pertambahan berat Gracilaria tiap 10 hari menunjukan pertumbuhan yang sangat berbeda sangat nyaya $(p=0.000 \leq 0,001)$ dan adanya korelasi antara waktu dan pertambahan berat $\left(R^{2}=0,85\right)$. Lambatnya pertambahan berat pada awal pemeliharaan $(0-10$ hari, $10-20$ hari dan $20-30$ hari) kemungkinan rumput laut masih beradapatasi terhadap lingkungan baru (Yong et al., 2014). Rumput laut yang cepat menyesuaikan diri dengan lingkungan barunya akan mampu tumbuh dengan cepat dan pertumbuhan optimal (Mulyaningrum et al., 2015). Lebih lanjut tentang adaptasi rumput laut Gracilaria untuk tumbuh selama budidaya (Nadir et al., 2019). Adaptasi yang diperlukan Gracilaria yang dipelihara di tambak Mangunharjo untuk tumbuh secara signifikan dimulai pada hari ke 30 sampai berakirnya pengamatan.

Tumbuh dan berkembangnya rumput laut dalam budidaya tidak hanya tergantug pada rumput lautnya namun juga pada kualitas perairan. Adapun hasil pengukuran kualitas air tambak dimana Gracilaria ditanam terlihat dalam Tabel 1.

Tabel 1. Kualitas air yang diukur di tambak Mangunharjo

\begin{tabular}{ll}
\hline \multicolumn{1}{c}{ Kualitas Air } \\
\hline Salinitas & $27-33 \mathrm{ppt}$ \\
Suhu Air & $24-26^{\circ} \mathrm{C}$ \\
$\mathrm{pH}$ & $7.1-7.3$ \\
Nitrat terlarut & $0,32 \mathrm{ppm}$ \\
Posfat terlarut & $0,25 \mathrm{ppm}$ \\
\hline
\end{tabular}

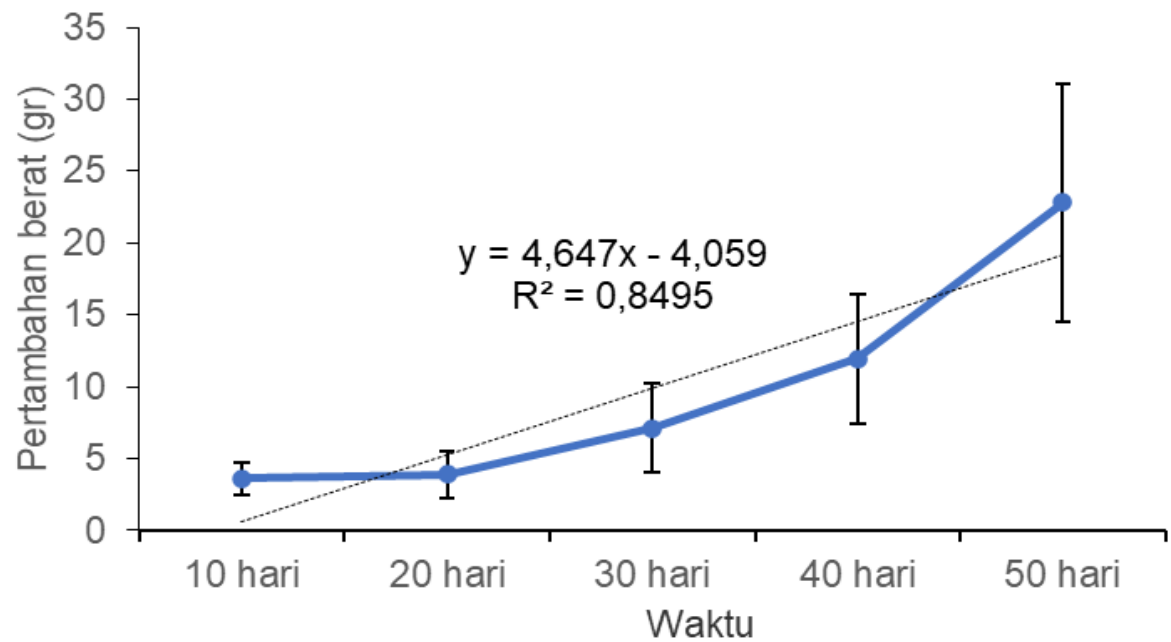

Gambar 2. Rata rata pertambahan berat \pm sd rumput laut Grcillaria sp di Tambak Mangunharjo

Beberapa penelitian menunjukan bahwa salinitas yang cocok untuk Gracilaria sp. tumbuh berkisan antara 15-35 ppt (Widyorini, 2010; Nadir et al. 2019). Kondisi tersebut memungkinkan Gracilaria untuk dibudidayakan di tambak seperti di daerah penelitian. Suhu dan pH perairan tambak di lokasi penelitian juga menunjukan kisaran suhu dan $\mathrm{pH}$ yang optimal untuk pertumbuhan rumput laut. Gracilaria sp. memiliki toleransi yang tinggi terhadap suhu perairan antara $0-35^{\circ} \mathrm{C}$ (Kim et al. 2016). Peran dari suhu perairan sebenarnya sangat luas bagi organisme salah satunya peningkatan metabolisme, bila metabolisme meningkat tentunya pertumbuhan juga akan meningkat. Namun suhu perairan dapat juga menyebabkan kematian bagi Gracilaria sp.bila suhu perairan berubah secara mendadak Hendri et al. (2017). pH dalam air memiliki peran dalam metabolise rumput laut dan $\mathrm{pH}$ yang baik antara 7-8, $\mathrm{pH}$ dalam lokasi penelitian dapat dikatakan masih dalam kisaran yang baik untuk Gracilaria sp. tumbuh Bezerra \& Marinho-Soriano (2010). Meskipun konsentrasi posfat dan nitrat terarut dalam perairan sangat kecil namun mereka memiki peran penting dalam pembentukan sel sehingga pertumbuhan Gracilaria sp. sangat tergntung padanya Jeslin et al. (2018). Namun optimal kisaran untuk nitrat untuk tumbuh Gracilaria antara 
0,6-0,8 ppm (Ganesan et al., 2011). Hasil pengukuran nitrat selama penelitian menunjukan nilai yang masih rendah bila dibandingkan dengan kisaran kisaran optimal untuk Gracilaria untuk tumbuh, hal tersebut juga terefleksikan dengan lambatnya pertumbuhan Gracilaria di tambak penelitian. Selain nitrat posfat juga merupakan mineral yang sangat penting untuk pertumbuhan Gracilaria yang dibudidayakan, sedangkan hasil pengukuran 0,25 ppm hal tersebut masih dapat dikatan cukup untuk Gracillria tumbuh. Kisaran konsentrasi nitrat dan posfat dalam perairan yang masih layak untuk pentumbuhan Gracilaria berkisar 0,1-3,5 ppm (Rejeki et al. 2018). Sedangkan Amir (2019) mengiformasikan nitrat yang lanyak untuk Gracilaria antara 0,01-0,79 ppm dan posfat antara 0,02-1 ppm.

\section{Kesimpulan}

Hasil penelitian menunjukan bahwa Gracilaria sp. yang ditumbuhkan dalam tambak mampu tumbuh secara meningkat beratnya setalah 30 hari. Hasil uji berat rumput laut pada waktu penanaman $(p=0.000 \leq 0,001)$. Penambahan berat terlihat secara signifikan pada hari ke 30-50 hari penanaman.

\section{Ucapan Terimakasih}

Artikel ini merupakan bagian dari pengabdian masyarakat: Budidaya rumput laut di tambak untuk peningkatan produksi di Desa Mangunharjo Kecamatan Tugu Kota Semarang dibiayai dengan dana Selain APBN Sukpa FPIK Undip dengan nomor kontrak 685/UN7.5.10.2/PM/2020

\section{Daftar Pustaka}

Alamsjah, M.A., Ayuningtiaz. N.O., \& Subekti, S. 2010. Pengaruh lama penyinaran terhadap pertumbuhan dan klorofil a Gracilaria verrucosa pada sistem budidaya indoor. Jurnal IImiah Perikanan dan Kelautan, 2(1):21-30.

Amir, M.R., 2019. Studi kelayakan tambak untuk budidaya rumput laut (Gracilaria sp.) di Desa Panyiwi Kecamatan Cenrana Kabupaten Bone. Jurnal Enviromental Science, 1(2):28-42

Anggadiredja, J.T., Zatnika, A., Purwoto, H. \& Istini, S., 2007. Rumput Laut. Penebar Swadaya. Jakarta. 152 hal

Aslan, M.L. 1998. Budidaya rumput laut. Kanisius. Yogyakarta. $105 \mathrm{pp}$

Bezerra, A.F. \& Marinho Soriano, E., 2010. Cultivation of the red seaweed Gracilaria birdiae (Gracilariales, Rhodophyta) in tropical waters of northeast Brazil. Biomass Bioenergy, (34): 1813-1817

FAO (Food and Agriculture Organization of the United Nations), 2012. The state of world fisheries and aquaculture. Opportunities and challenges.

Ganesan, M., Sahu, N., \& Eswaran, K., 2011. Raft Culture of Gracilaria edulis in Open Sea Along The South-eastern Coast of India. Aquaculture. (321):145-151

Hendri, M., Rozirwan., \& Rezi, A. 2017. Optimization of Gracilaria sp. cultivation using vertikultur system. International Journal of Marine Science. 7(43):411-422

Jeslin, Rahmat, S.P., \& Abdul, R., 2018. Pengaruh jarak tanam bibit yang berbeda terhadap pertumbuhan dan produksi rumput laut (Gracilaria verrucosa) Menggunakan Metode Longline di Tambak. Media Akuatika. 3(1):639-648.

Kim, J.K., Yarish, C., \& Pereira, R. 2016. Tolerances to Hypo-osmotic and temperature stresses in native and invasive species of Gracilaria (Rhodophyta). Phycologia. 55(3):257-264

Marinho-Soriano, E., Moreira, W.S.C. \& Carneiro, M.A.A., 2006. Some aspects of the growth of Gracilaria birdiae (Gracilariales, Rhodophyta) in an estuary in northeast Brazil. Aquaculture International 14:327-336. doi: 10.1007/s10499-005-9032-z

McLachlan J. \& Bird C.J. 1986. Gracilaria (Gigartinales, Rhodophyta) and productivity. Aquatic Botany. 26:27-49 
Mulyaningrum, S.R.H., Parenrengi, A. \& Suryati, E., 2015. Pertumbuhan dan perkembangan eksplan rumput laut Gracilaria verrucosa dan Gracilaria gigas pada aklimatisasi di tambak. IImu Kelautan, 20(3):135-142

Nadlir, A., Susilowati, T., Adi, K., Harwanto, D., Haditomo, A.H.C., \& Windarto, S., 2019., Production performance of Gracilaria verrucosa using verticulture method with various wide planting area in Karimunjawa. Omni Akuatika, 15(1):47-58. doi :10.20884/1.oa.2019.15.1.671

Parker, R., 2012. Aquaculture Science. Third Edition. Delmar. New York. 652p.

Pong-Masak, P.R., \& Nelly, H.S. 2015. Teknologi budidaya rumput laut dengan metode vertikultur. Penerbit: Loka Penelitian dan Pengembangan Budidaya Rumput Laut. 29 pp.

Putra, B.D., Aryawati, R. \& Isnaini. 2011. Laju pertumbuhan rumput laut Gracilaria sp. dengan metode penanaman yang berbeda di perairan Kalianda, Lampung Selatan. Maspari Journal 3: 36-41

Rejeki, S., Ariyati. R.W., Widowati, L.L., \& Bosma, H.H., 2018. The effect of three cultivation methods and two seedling types on growth, agar content and gel strength of Gracilaria verrucosa. Egyptian Journal of Aquatic Research, 44:65-70.

Ruslaini. 2016. Kajian kualitas air terhadap pertumbuhan rumput laut (Gracilaria verrucosa) di tambak dengan metode vertikultur. Jurnal Octopus. 5(2):522-526

Thanigaivel, S., Chandrasekaran, N., Mukherjee, A. \& Thomas, J., 2016., Seaweeds as an alternative therapeutic source for aquatic disease management. Aquaculture 464: 529-536

Vatsos, I.N. \& Rebours, C., 2015. Seaweed extracts as antimicrobial agents in aquaculture. Journal of Applied Phycology, 27(5):2017-2035

Widyorini, N. 2010. Analisis Pertumbuhan Gracilaria sp. di tambak udang ditinjau dari tingkat sedimentasi. Jurnal Saintek Perikanan. 6(1):30-36

Yong, Y.S., Yong, W.T.L., Thien, V.Y., Ng, S.E., Anton, A \& Yassir, S., 2014. Acclimatization of micropropagated Kappaphycus alvarezii (Doty) Doty ex Silva (Rhodophyta, Solieriaceae) in outdoor nursery system. Journal of Applied Phycology, 26(1):1-7. doi: 10.1007/s10811-0140289-3

Zemke-White, W.L. \& Ohno, M.,1999. World seaweed utilization: an end-of century summary. Journal of Applied Phycology, 11:369-376 